\title{
UTJECAJ UVJETA SKLADIŠTENJA NA KLIJAVOST SJEMENA POVRTNIH VRSTA
}

\author{
Dijana HORVAT ${ }^{1}$, Iva ROJNICA ${ }^{1}$, Marina PALFI ${ }^{2}$, Ivana KOPRIVNJAK ${ }^{1}$, \\ Helena TOMIĆ - OBRDALJ ${ }^{2}$ \\ ${ }^{1}$ Visoko gospodarsko učilište u Križevcima, \\ Krizevci Collage of Agriculture \\ ${ }^{2}$ Podravka d.d., Istraživanje i razvoj \\ Podravka d.d., Research and Development
}

\section{SAŽETAK}

Sjeme povrtnih vrsta namijenjeno vrtlarima hobistima uglavnom je iz uvoza, kategorije standard i pakirano u sitnim pakiranjima. Uvoznici koji prepakiravaju sjeme obavezni su nakon pakiranja ispitati klijavost. Neprodane količine sjemena povlače se s tržišta na kraju sezone i plasiraju u iduće dvije do tri sezone bez kontrole klijavosti te se događa da sjeme u prodaji ima lošu klijavost ili uopće nije klijavo.

Cilj istraživanja bio je ispitati klijavost sjemena 24 povrtne vrste na uzorcima partija sjemena skladištenih $u$ klimatiziranom skladištu i na uzorcima istih partija koje je na tržištu dvije vegetacijske sezone te usporediti $\mathrm{s}$ ispitanom klijavosti nakon uvoza. Istraživanjem je utvrđeno da klijavost sjemena celera listaša (Apium graveolens var. secalinum L.), celera korjenaša (Apium graveolens L.), peršina listaša (Petroselium crispum ssp. crispum L.), poriluka (Allium porrum L.), boba (Vicia faba L.), paprike (Capsicum annuum L.) i špinata (Spinacia oleracea L.)pada neovisno o uvjetima skladištenja, dok uvjeti skladištenja značajno utječu na klijavost kupusa (Brassica oleracea L.), brokule (Brassica oleracea L. var. italica), salate (Lactuca sativa L.) i cikle (Beta vulgaris L. var. conditiva). Od ukupno 24 partije sjemena povrtnih vrsta uzorkovanih u skladištu dorađivača (uvoznika) njih $46 \%$ nakon 20 mjeseci ne zadovoljava propisanu minimalnu klijavost, dok od istih partija sjemena uzorkovanih u skladištu laboratorija (kontrolirani uvjeti) ne zadovoljava njih $29 \%$.

Skladištenjem sjemena na temperaturi $15^{\circ} \mathrm{C}$ na tamnom i suhom mjestu te kontrolom klijavosti nakon svake vegetacijske sezone može se značajno utjecati na kvalitetu sjemena povrtnih vrsta na tržištu.

Ključne riječi: sjeme povrtnih vrsta, klijavost, uvjeti skladištenja 
Dijana Horvat i sur.: Utjecaj uvjeta skladištenja

na klijavost sjemena povrtnih vrsta

\section{UVOD}

Proizvodnja povrtnih vrsta ima u Hrvatskoj dugu tradiciju posebno u ruralnim sredinama gdje je povrtnjak neizostavni dio svakog poljoprivrednog gospodarstva. Buđenjem svijesti o zdravoj prehrani povećava se i broj povrtnjaka u urbanim sredinama, posebno formiranjem ,gradskih vrtova“ koji danas postoje gotovo u svim gradovima. Osim proizvodnje povrtnih vrsta za vlastite potrebe, povrtnjak ima važnu sociološku ulogu u urbanim sredinama jer predstavlja sigurno mjesto za boravak na otvorenom, druženje, razmjenu iskustava i sjemena. Iako razmjenjuju sjeme, većinu sjemena vrtlari nabavljaju u poljoprivrednim apotekama, vrtnim i trgovačkim centrima.

Ponuda sjemena namijenjena vrtlarima hobistima bazira se na sjemenu iz uvoza, kategorije standardno sjeme. Iz godine u godinu povećavaju se uvezene količine sjemena, broj vrsta i sorata, a samim time raste broj uvoznika i dorađivača sjemena. Dio uvoznika uvozi sjeme pakirano u sitna pakiranja, dok uvoznici koji su ujedno i dorađivači sjemena, uvoze sjeme u rinfuzi i pakiraju ga u sitna pakiranja. Kvaliteta sjemena uvezenog u sitnim pakiranjima ne kontrolira se prilikom uvoza, dok su uvoznici dorađivači obavezni nakon pakiranja ispitati energiju i klijavost spakiranog sjemena. Neprodane količine sjemena dorađivači nakon sezone povlače s tržišta i ponovo plasiraju na tržište sljedeće dvije ili tri sezone. Iako dorađivači sjemena povrtnih vrsta kontroliraju kvalitetu sjemena nakon pakiranja često se događa da je sjeme koje kupuju vrtlari hobisti loše klijavo ili uopće nije klijavo, što potvrđuju i kontrole kvalitete sjemena na tržištu od strane Inspekcije u poljoprivredi.

Uzroci loše klijavosti sjemena povrtnih vrsta na tržištu mogu biti različiti od nepravilnog skladištenja, utjecaja same vrste na duljinu klijavosti sjemena ili plasiranja sjemena loše kvalitete na tržište.

Cilj provedenog istraživanja je ispitati klijavost sjemena povrtnih vrsta nakon dvadeset mjeseci skladištenja u kontroliranim i nekontroliranim uvjetima te ih usporediti s klijavosti nakon uvoza da bi utvrdili koji faktori utječu na klijavost sjemena.

\section{PREGLED LITERATURE}

Kvaliteta sjemena je kompleksno svojstvo (R o z m a n i sur., 2009.) koje ovisi o agroekološkim uvjetima tijekom vegetacije (M c D o n a 1 d, 1998.), geografskom području uzgoja, lokaciji i klimatskim faktorima u godini uzgoja. Kontinentalna klima s proljetnim oborinama i vrućim i suhim ljetom pogodna je za uzgoj jednogodišnjih povrtnih vrsta (Lešić i sur., 1993.). Osim agroekoloških uvjeta na kvalitetu sjemena utječe način žetve (berbe) i proces dorade sjemena (S c h a f f e r i Vanderlip, 1999.), pri čemu može doći do oštećenja sjemena, što uzrokuje smanjene klijavosti.

Energija klijanja i klijavost sjemena najvažniji su pokazatelji kvalitete sjemena. Energija klijanja utvrđuje se kao informativni podatak o broju normalnih klijanaca prema ukupnom broju sjemenki stavljenih na klijanje nakon proteka vremena 
Dijana Horvat i sur.: Utjecaj uvjeta skladištenja

na klijavost sjemena povrtnih vrsta

predviđenog za ovo ocjenjivanje (NN 99/08). Klijavost sjemena je utvrđen broj normalnih klijanaca prema ukupnom broju sjemenki stavljenih na klijanje, koji se utvrđuje nakon proteka vremena predviđenog za završno ocjenjivanje (NN 99/08). Sjeme povrtnih vrsta koje se stavlja na tržište mora imati minimalnu propisanu klijavost (NN 129/07., 43/13.).

Na klijavost sjemena utječe niz faktora, a jedan od najvažnijih je skladištenje sjemena. Uvjeti i duljina skladištenja značajno utječu na klijavost (Vieira i sur., 2001.), pri čemu najvažniju ulogu u očuvanju klijavosti imaju vlaga sjemena, temperatura i relativna vlažnost zraka u skladištu (Rozman i sur., 2009.). Osiguravanjem odgovarajućih uvjeta skladištenja sprečavamo narušavanje kvalitete sjemena, a niska temperatura i niska vlaga sjemena dva su najučinkovitija faktora za održavanje kvalitete sjemena u skladištu (E1lis i sur., 1985 ; Delouche, 1990.).Vlaga sjemena varira kod različitih vrsta kao rezultat razlika u kemijskom sastavu sjemena $i$ uvjetima koji vladaju tijekom razvoja i sazrijevanja sjemena (D o i j o d e, 2012). Osim o temperaturi skladištenja, sadržaju vlage u sjemenu i duljini skladištenja pad kvalitete sjemena ovisi o vrsti sjemena i samoj kvaliteti sjemena prije skladištenja (Amjad i Anjum, 2002.). Životna sposobnost sjemena razlikuje se među rodovima, vrstama, a ponekad i među genotipovima (James, 1967.) jer se procesi koji uzrokuju starenje sjemena kod nekih vrsta odvijaju brže, a kod nekih sporije (B e l o š e v i ć - Tu b i ć 2001.). O biljnoj vrsti ovise $i$ optimalni uvjeti skladištenja sjemena pa se sjeme nekih biljnih vrsta može čuvati dulje od drugih (Elias i sur., 2002.). Idealni uvjeti za skladištenje sjemena povrtnih vrsta su vlaga sjemena do $10 \%$, temperatura ispod $0^{\circ} \mathrm{C} \mathrm{i}$ relativna vlažnost zraka $68 \%$, ali se iz ekonomskih razloga u tim uvjetima čuva samo najvrjednije sjeme (Lešić i sur. 1993.), primjerice sjeme u gen bankama koje se čuva dugoročno. Vlaga sjemena do $10 \%$, temperatura do $15^{\circ} \mathrm{C}$ i vlaga zraka do $40 \%$ bili bi optimalni uvjeti za čuvanje sjemena kategorije standard koje se čuva do tri godine.

\section{MATERIJAL I METODE}

Istraživanje je provedeno u Laboratoriju za kontrolu kakvoće poljoprivrednog reprodukcijskog materijala Visokoga gospodarskog učilišta u Križevcima na 24 uzorka sjemena povrtnih vrsta (Tablica 1.) skladištenih u kontroliranim i nekontroliranim uvjetima. Nakon uvoza i pakiranja izvršeno je uzorkovanje certificiranog sjemena povrtnih vrsta kod uvoznika prema partijama, te je ispitana klijavost i izdano izvješće o kvaliteti. Nakon 20 mjeseci provedeno je uzorkovanje istih partija sjemena povrtnih vrsta kod uvoznika (dorađivača) nakon što je sjeme povučeno s tržišta. Uzorkovane partije sjemena bile su tijekom dvije sezone na tržištu, a izvan sezone skladištene u skladištu uvoznika u nekontroliranim uvjetima. Ispitivanje je provedeno i na istim partijama sjemena koje su skladištene u skladištu laboratorija na temperaturi od $15^{\circ} \mathrm{C} \mathrm{u}$ tami (kontrolirani uvjeti). Uzeti su prosječni uzorci od kojih su metodom prepolavljanja formirani radni uzorci na kojima su provedene analize klijavosti sjemena. Klijavost sjemena ispitana je prema Pravilniku o metodama uzorkovanja $\mathrm{i}$ ispitivanja kvalitete 
sjemena (NN 99/08.) (Tablica 1.), u komori za naklijavanje. Termomedicinski aparati „Bodalec“ na propisanoj temperaturi (Tablica 1.) pri svjetlosnom režimu 12 sati dan/12 sati noć.

Tablica 1. Povrtne vrste korištene u istraživanju i propisane metode ispitivanja klijavosti sjemena Table 1 Vegetable species used in the study and prescribed methods for testing seed germination

\begin{tabular}{|c|c|c|c|}
\hline Povrtna vrsta /Vegetablespecies & $\begin{array}{c}\text { Podloga, } \\
\text { temperatura u } \\
\mathrm{C}^{\mathrm{o}} / \text { Substrate, } \\
\text { temperature in } \\
{ }^{\circ} \mathrm{C} \\
\end{array}$ & $\begin{array}{c}\text { Prvo - završno } \\
\text { ocjenjivanje broj } \\
\text { dana/First- } \\
\text { lastassessment } \\
\text { (numberofdays) }\end{array}$ & $\begin{array}{l}\text { Predtretman/ } \\
\text { Pretreatment }\end{array}$ \\
\hline $\begin{array}{l}\text { Celer lišćar (Apium graveolens var. secalinum L.) } \\
\text { Celer korjenaš (Apium graveolens } \mathrm{L} \text {.) }\end{array}$ & NF, $20-30$ & $7-21$ & PH \\
\hline Peršin lišćar (Petroselium crispum ssp. crispum L.) & NF, $20-30$ & $10-28$ & - \\
\hline Špinat (Spinacia oleracea L.) & NF, 15 & $7-21$ & $\mathrm{PH}$ \\
\hline Paprika (Capsicum anuum L.) & NF, 20-30 & $7-14$ & $\mathrm{KNO}_{3}$ \\
\hline Poriluk (Allium porrum L.) & NF, 20 & $6-14$ & $\mathrm{PH}$ \\
\hline Bob (Vicia faba L.) & $P, 20$ & $4-14$ & $\mathrm{PH}$ \\
\hline Kupus (Brassica oleracea var. capitata L.) & NF, $20-30$ & $5-10$ & $\mathrm{PH}$ \\
\hline \multicolumn{4}{|l|}{ Brokula (Brassica oleracea var. italica L.) } \\
\hline Salata (Lactuca sativa L.) & $\mathrm{NF}, 20$ & $4-7$ & $\mathrm{PH}$ \\
\hline Cikla (Beta vulgaris subsp. vulgaris var. coditiva L.) & $\mathrm{IF}, 20$ & $4-7$ & $\begin{array}{l}\text { upotreba FF } \\
\text { PI, } 2 \mathrm{~h}\end{array}$ \\
\hline Mrkva (Daucu scarota L.) & NF, 20-30 & $7-14$ & - \\
\hline Matovilac (Valerianella locusta (L.) Laterr.) & NF, 20 & $7-28$ & $\mathrm{PH}$ \\
\hline Endivija (Cichorium endivia L.) & NF, 20-30 & $5-14$ & $\mathrm{PH}$ \\
\hline Radič (Cichorium intybus L.) & NF, $20-30$ & $5-14$ & $\mathrm{KNO}_{3}$ \\
\hline Grašak (Pisum sativum L.) & $\mathrm{P}, 20$ & $5-8$ & - \\
\hline $\begin{array}{l}\text { Grah zrnaš (Phaseolus vulgaris L. ssp. vulgaris var.nanus } \\
\text { f. fibriferis) }\end{array}$ & $\mathrm{P}, 20-30$ & $5-9$ & - \\
\hline \multicolumn{4}{|l|}{$\begin{array}{l}\text { Grah mahunar (Phaseolus vulgaris ssp.vulgaris var. } \\
\text { nanus } f \text {. sine fibris) }\end{array}$} \\
\hline Tikvica (Cucurbita pepo L.) & $P, 20-30$ & $4-8$ & - \\
\hline Krastavac (Cucumis sativus L.) & IF, $20-30$ & $4-8$ & upotreba FF \\
\hline Patlidžan (Solanum melogena L.) & NF, $20-30$ & $7-14$ & - \\
\hline Lubenica (Citrulus lantaus (Thunb) Matsum. et Nakai) & IF, $20-30$ & $5-14$ & upotreba FF \\
\hline Dinja (Cucumis melo L.) & IF, 20-30 & $4-8$ & upotreba FF \\
\hline Rajčica (Lycopersicon esculentum Mill.) & NF, $20-30$ & $5-14$ & $\mathrm{KNO}_{3}$ \\
\hline
\end{tabular}

Kod ispitivanja metodom na filtar papiru (NF) sjeme je stavljeno na dva sloja filtar papira u sterilizirane petrijeve zdjelice, dok je kao metoda između filtar papira (IF) korišten faltani filtar papir (FF), između kojeg je stavljeno sjeme, po dvije sjemenke u jedan nabor. Metoda u pijesku (P) primijenjena je kod povrtnih vrsta koje imaju krupno sjeme koje je stavljeno na sloj navlaženog steriliziranog pijeska i prekriveno tankim slojem pijeska. Za vlaženje podloge korištena je destilirana voda, osim kod vrsta kod kojih je propisano vlaženje podloge $0,2 \%$ otopinom $\mathrm{KNO}_{3}$ (Tablica 1.). Prema propisanim metodama $\mathrm{u}$ Tablici 1 . kod određenih vrsta proveden je predtretman prethodno hlađenje (PH) u svrhu prekida doramantnosti (mirovanja) sjemena. Sjeme je na podlozi za naklijavanje stavljeno na sedam dana u hladnjak na temperaturu od $5^{\circ} \mathrm{C}$, 
Dijana Horvat i sur.: Utjecaj uvjeta skladištenja

na klijavost sjemena povrtnih vrsta

nakon čega je premješteno u komoru za naklijavanje. Za otklanjanje inhibitora klijanja u sjemenu cikle (Beta vulagris subsp. vulgaris var. conditiva L.) korišten je predtretman ispiranja sjemena u trajanju od dva sata (Tablica 1.). Kod svih povrtnih vrsta klijavost sjemena ispitana je u četiri ponavljanja po 100 sjemenki. Prvo ocjenjivanje predstavlja energiju klijanja, a završno ocjenjivanje klijavost sjemena. Broj dana za ocjenjivanje energije i klijavosti različiti su od vrste do vrste (Tablica 1.). Klijavost sjemena izražena je kao postotak normalnih klijanaca, a izračunata je kao srednja vrijednost svih četiriju ponavljanja.

Statistička analiza je provedena s ciljem utvrđivanja utjecaja različitih uvjeta skladištenja na klijavost sjemena pojednih povrtnih vrsta. Ispitivanje je provedeno u 4 ponavljanja za svaku biljnu vrstu. Podaci su izraženi kao aritmetička sredina +/standardna devijacija (Tablica 2.). Za utvrđivanje statističke razlike između klijavosti pri raznim uvjetima skladištenja korišten je ne-parametrijski Mann-Whitney U test, statistička značajnost je na razini $\mathrm{p}<0,05$.

Za utvrđivanje korelacija biljne vrste i uvjeta skladištenja na klijavost korišten je Perasonov koeficijent korelacije (Tablica 3.). Statistička analiza je provedena $u$ programu Past v 2.17c.

\section{REZULTATI I RASPRAVA}

Rezultati ispitivanja klijavosti sjemena svake povrtne vrste nakon uvoza i nakon 20 mjeseci skladištenja u kontroliranim i nekontroliranim uvjetima prikazani su u Tablici 2. Korelacija povrtne vrste i uvjeta skladištenja izražena je Pearsonovim koeficijentom u Tablici 3.

Uvjeti skladištenja, i kontrolirani i nekontrolirani imaju jak utjecaj na klijavost sjemena povrtnih vrsta. $\mathrm{Na}$ osnovi rezultata vidljivo je da klijavost sjemena celera listašastatistički značajno opada i u kontroliranim i nekontroliranim uvjetima $(p<0,05)$, pri čemu je nešto jači pad zabilježen kod nekontroliranih uvjeta. Sjeme celera korjenaša nakon 20 mjeseci skladištenja uopće nije klijavo (0\%), što se može tumačiti kemijskim sastavom sjemena koje je bogato eteričnim uljima ( $\mathrm{S}$ h a d i sur., 2011.) koja otežavaju bubrenje sjemena i usporavaju klijanje (L e š i ć i sur., 1993.). Značajan pad klijavosti $\mathrm{u}$ oba uvjeta $(\mathrm{p}<0,05)$ skladištenja $\mathrm{u}$ odnosu na klijavost nakon uvoza vidljiv je kod peršina listaša, s tim da klijavost značajnije pada pri nekontroliranim uvjetima skladištenja. Zbog prisutnosti inihibitora klijanja u sjemenoj ljusci i nezrelosti embrija sjeme peršina klije sporo i neujednačeno, a klijavost zadržava dvije do tri godine (Lešić i sur., 1993; Skromak 2016.), što se slaže s rezultatima dobivenim ovim istraživanjem. Klijavost sjemena špinata, paprike, poriluka, graška i boba nakon skladištenja u oba uvjeta $(\mathrm{p}<0,05)$ statistički značajno i podjednako pada u odnosu na klijavost nakon uvoza. Navedeni rezultati dokazuju tvrdnju da skladištenje i čuvanje sjemena ovisi o njegovoj dugovječnosti odnosno o biljnoj vrsti (Lešić i sur., 1993; Amjad i Anjum, 2002; Elias i sur., 2002.). Klijavost sjemena poriluka i špinata 


\section{Dijana Horvat i sur.: Utjecaj uvjeta skladištenja na klijavost sjemena povrtnih vrsta}

Tablica 2. Klijavost sjemena (\%) povrtnih vrsta nakon uvoza i nakon 20 mjeseci skladištenja u kontroliranim i nekontroliranim uvjetima izražena kao srednja vrijednost +/- standardna devijacija.

Table 2 Seed germination (\%) of vegetable species after import and after 20 months of storage in controlled and uncontrolled conditions, expressed as a mean $+/-$ standard deviation.

\begin{tabular}{|c|c|c|c|}
\hline Povrtna vrsta/Vegetablespecies & $\begin{array}{l}\text { Klijavost nakon } \\
\text { uvoza } \\
\text { /Germination } \\
\text { after import (\%) }\end{array}$ & $\begin{array}{c}\text { Klijavost u } \\
\text { kontroliranim } \\
\text { uvjetima } \\
\text { skladištenja } \\
\text { /Germination in } \\
\text { controlled storage } \\
\text { conditions (\%) }\end{array}$ & $\begin{array}{c}\text { Klijavost u } \\
\text { nekontroliranim } \\
\text { uvjetima skladištenja } \\
\text { /Germination in } \\
\text { uncontrolled storage } \\
\text { conditions (\%) }\end{array}$ \\
\hline $\begin{array}{l}\text { Celer lišćar (Apium graveolens var. } \\
\text { secalinum L.) }\end{array}$ & $81 \pm 1,63^{\mathrm{a}}$ & $43 \pm 1,83^{b}$ & $28 \pm 2,16^{\mathrm{c}}$ \\
\hline Celer korijen (Apium graveolens L.) & $81 \pm 1,41^{\text {a }}$ & $0 \pm 0,50^{\mathrm{b}}$ & $0 \pm 0,00^{\mathrm{b}}$ \\
\hline $\begin{array}{l}\text { Peršin lišćar (Petroselinum crispum ssp. } \\
\text { crispum L.) }\end{array}$ & $67 \pm 1,83^{\mathrm{a}}$ & $22 \pm 3,65^{\mathrm{b}}$ & $5 \pm 1,83^{\mathrm{c}}$ \\
\hline Špinat (Spinaca oleracea L.) & $84 \pm 1,83^{\mathrm{a}}$ & $43 \pm 1,83^{\mathrm{b}}$ & $44 \pm 2,58^{\mathrm{b}}$ \\
\hline Paprika (Capsicum annum L.) & $73 \pm 1,83^{\text {a }}$ & $63 \pm 2,94^{b}$ & $60 \pm 1,83^{b}$ \\
\hline Poriluk (Allium porum L.) & $77 \pm 3,56^{\mathrm{a}}$ & $30 \pm 2,58^{b}$ & $32 \pm 3,16^{b}$ \\
\hline Bob (Vicia faba L.) & $95 \pm 1,83^{a}$ & $46 \pm 2,71^{b}$ & $46 \pm 1,41^{b}$ \\
\hline Kupus (Brassica oleracea var. capitata L.) & $80 \pm 2,16^{\mathrm{a}}$ & $76 \pm 1,83^{a}$ & $65 \pm 1,63^{b}$ \\
\hline Brokula (Brassica oleracea var. italica L.) & $82 \pm 2,58^{\mathrm{a}}$ & $81 \pm 1,83^{\mathrm{a}}$ & $59 \pm 1,83^{b}$ \\
\hline Salata (Latuca sativa L.) & $93 \pm 1,83^{\text {a }}$ & $80 \pm 3,65^{b}$ & $49 \pm 2,16^{c}$ \\
\hline $\begin{array}{l}\text { Cikla (Beta vulagris subsp. vulgaris var. } \\
\text { conditiva } \mathrm{L} \text {.) }\end{array}$ & $82 \pm 2,58^{\mathrm{a}}$ & $57 \pm 2,58^{b}$ & $15 \pm 2,58^{\mathrm{c}}$ \\
\hline Mrkva (Daucus carota L.) & $84 \pm 3,16^{\text {a }}$ & $73 \pm 2,16^{b}$ & $79 \pm 3,37^{\text {a }}$ \\
\hline $\begin{array}{l}\text { Matovilac (Valerianella locusta (L.). } \\
\text { Laterr.) }\end{array}$ & $87 \pm 2,58^{\text {a }}$ & $78 \pm 1,83^{b}$ & $72 \pm 1,83^{c}$ \\
\hline Endivija (Cichorium endivia L.) & $90 \pm 1,83^{\mathrm{a}}$ & $85 \pm 3,65^{\mathrm{a}}$ & $82 \pm 2,94^{b}$ \\
\hline Radič (Cichorium intybus L.) & $90 \pm 1,83^{\mathrm{a}}$ & $87 \pm 1,83^{\mathrm{a}}$ & $89 \pm 2,94^{\text {a }}$ \\
\hline Grašak (Pisum arvense L.) & $96 \pm 1,83^{\text {a }}$ & $85 \pm 2,94^{\mathrm{b}}$ & $88 \pm 2,58^{b}$ \\
\hline $\begin{array}{l}\text { Grah zrnaš (Phaseolus vulgaris L. ssp. } \\
\text { vulgaris var.nanus f. fibriferis) }\end{array}$ & $89 \pm 1,82^{\text {a }}$ & $87 \pm 2,94^{\mathrm{a}}$ & $89 \pm 3,65^{\mathrm{a}}$ \\
\hline Tikvica (Cucurbita pepo L.) & $97 \pm 1,83^{\text {a }}$ & $93 \pm 1,83^{\mathrm{b}}$ & $83 \pm 2,58^{\mathrm{c}}$ \\
\hline Krastavac (Cucumis sativus L.) & $97 \pm 0,82^{b}$ & $99 \pm 0,82^{a}$ & $96 \pm 1,41^{b}$ \\
\hline Patlidžan (Solanum melongena L.) & $89 \pm 1,83^{\mathrm{b}}$ & $94 \pm 2,94^{\mathrm{a}}$ & $81 \pm 2,16^{c}$ \\
\hline $\begin{array}{l}\text { Lubenica (Citrulllus lanatus (Thunb) } \\
\text { Matsum. et Nakai) }\end{array}$ & $95 \pm 2,16^{\mathrm{b}}$ & $100 \pm 0,00^{\mathrm{a}}$ & $95 \pm 0,82^{b}$ \\
\hline Dinja (Cucumis melo L.) & $83 \pm 3,16^{b}$ & $93 \pm 3,37^{\mathrm{a}}$ & $88 \pm 1,83^{\mathrm{ab}}$ \\
\hline Rajčica (Lycopersicon esculentum Mill.) & $86 \pm 2,58^{\mathrm{a}}$ & $88 \pm 1,83^{\mathrm{a}}$ & $87 \pm 1,63^{\mathrm{a}}$ \\
\hline $\begin{array}{l}\text { Grah mahunar (Phaseolus vulgaris L. ssp. } \\
\text { vulgaris var. nanus } f \text {. sine fibris ) }\end{array}$ & $88 \pm 2,58^{\text {a }}$ & $91 \pm 1,83^{\mathrm{a}}$ & $76 \pm 4,40^{b}$ \\
\hline
\end{tabular}

Rezultati su izraženi kao aritmetička sredina $\pm \mathrm{SD}(\mathrm{n}=4)$; statistički značajna razlika $(\mathrm{p}<0,05)$./

Results are expressed as meanvalue $\pm \operatorname{SD}(n=4)$; statistically significant difference at $\mathrm{p}<0,05$ 
Dijana Horvat i sur.: Utjecaj uvjeta skladištenja

na klijavost sjemena povrtnih vrsta

Tablica 3. Korelacijska matrica (Pearsonov koeficijent) za klijavost povrtnih vrsta i uvjeta skladištenja Table 3 Correlation matrix (Pearson coefficients) of germination of vegetable species and different storage conditions

\begin{tabular}{lcccc}
\hline & $\begin{array}{c}\text { Kontrolirani } \\
\text { uvjeti } \\
\text { Vegetablespecies }\end{array}$ & $\begin{array}{c}\text { Nekontrolirani } \\
\text { uvjeti } \\
\text { skladištenja/ } \\
\text { Uncontrolled } \\
\text { skladištenja/ } \\
\text { storage conditions }\end{array}$ \\
\hline $\begin{array}{l}\text { Povrtna vrsta/ } \\
\text { Vegetablespecies } \\
\text { Klijavost nakon } \\
\text { uvoza/ }\end{array}$ & 1 & - & - & - \\
$\begin{array}{l}\text { Germination after } \\
\text { import }\end{array}$ & 0,5890 & 1 & - & - \\
$\begin{array}{l}\text { Kontrolirani uvjeti } \\
\text { skladištenja/ }\end{array}$ & 0,8427 & 0,6297 & & \\
$\begin{array}{l}\text { Controlled storage } \\
\text { conditions }\end{array}$ & & & & - \\
$\begin{array}{l}\text { Nekontronstirani } \\
\text { uvjeti skladištenja/ }\end{array}$ & 0,8200 & 0,6247 & 0,9155 & 1 \\
$\begin{array}{l}\text { Uncontrolled } \\
\text { storage conditions }\end{array}$ & & & & \\
\hline
\end{tabular}

značajno je pala u oba uvjeta skladištenja što je i očekivano jer je životni vijek sjemena ovih vrsta do tri godine. Ostale navedene vrste se ubrajaju se u skupinu čiji životni vijek je od tri do petnaest godina (Lešić i sur., 1993.), što se ne slaže s ovim istraživanjem prema kojem je vidljivo da je do značajnog pada klijavosti došlo već nakon 20 mjeseci. Rezultati dobiveni kod paprike slažu se $\mathrm{s}$ istraživanjem koje su proveli Ozcopan i Demir (2002.), a prema kojem sjeme paprike ima relativno kratak vijek trajanja i gubi kvalitetu tijekom skladištenja. Značajan pad klijavosti sjemena boba u oba uvjeta skladištenja ne slaže se sa tvrdnjom da sjeme boba zadržava klijavost pet do šest iznimno do deset godina (Lešić i sur., 1993.), te sa rezultatima klijavosti sjemena kod ostalih istraživanih mahunarki (Fabaceae). Sjeme boba osjetljivo je na manipulaciju tijekom skladištenja i transporta jer može doći do mehaničkog oštećenja, posebno ako je vlaga sjemena do $8 \%$. Manipulacija sjemenom bila je prisutna i u skladištu uvoznika i laboratorija te je kod boba potrebno provesti dodatna istraživanja da se utvrdi utječu li vrsta na klijavost sjemena nakon skladištenja ili mehanička oštećenja prilikom rukovanja s uzorcima.

Na pad klijavosti sjemena kupusa, brokule, graha mahunara i endivije statistički značajno utječu nekontrolirani uvjeti $(\mathrm{p}<0,05)$ skladištenja, dok je klijavost u kontroliranim uvjetima gotovo podjednaka kontroli te bi za dugoročno čuvanje sjemena ovih vrsta trebalo osigurati skladištenje u uvjetima kontrolirane temperature. Kod sjemena salate, cikle, matovilca i tikvice vidljiv je statistički značajan pad klijavosti kod oba uvjeta $(\mathrm{p}<0,05)$ skladištenja, no u nekontroliranim uvjetima je taj pad značajno veći. Rezultati dobiveni kod ovih vrsta slažu se $\mathrm{s}$ rezultatima istraživanja koja su proveli Amajd i Anjum, 2002; Rao i sur., 2006; 
Dijana Horvat i sur.: Utjecaj uvjeta skladištenja na klijavost sjemena povrtnih vrsta

Alhamdan i sur., 2011. U navedenim istraživanjima utvrđeno je da niža temperatura sa što manjim oscilacijama tijekom skladištenja utječe na očuvanje klijavosti i dugovječnost sjemena. Klijavost sjemena mrkve pada u oba uvjeta skladištenja, ali je pad klijavosti značajniji u kontroliranim uvjetima. Rezultati istraživanja pokazuju da nije bilo značajne razlike u klijavosti sjemena radiča, graha zrnaša i rajčice nakon 20 mjeseci skladištenja u kontroliranim i nekontroliranim uvjetima u usporedbi s klijavosti nakon uvoza. Sjeme ovih vrsta zadržava klijavost neovisno o uvjetima skladištenja, ali da bi utvrdili točan vremenski period trebalo bi provesti istraživanja na dulji rok skladištenja. Klijavost sjemena krastavca, patlidžana, lubenice i dinje statistički je značajno porasla nakon skladištenja u kontroliranim uvjetima u odnosu na klijavost nakon uvoza i klijavost u nekontroliranim uvjetima. Pravilno skladištenje kod ovih vrsta utječe na povećanje klijavosti, a skladištenje u lošijim uvjetima određeno vrijeme ne smanjuje klijavost jer nije bilo značajne razlike između klijavosti nakon uvoza i u nekontroliranim uvjetima skladištenja osim kod patlidžana kod kojeg nekontrolirani uvjeti skladištenja značajno utječu na pad klijavosti.

Slika 1. Postotak uzoraka čija klijavost je pala ispod minimalne propisane u skladištu dorađivača i laboratorija

Figure 1 Percentage of samples whose germination fell below the minimum prescribed in the warehouse of processors and laboratories

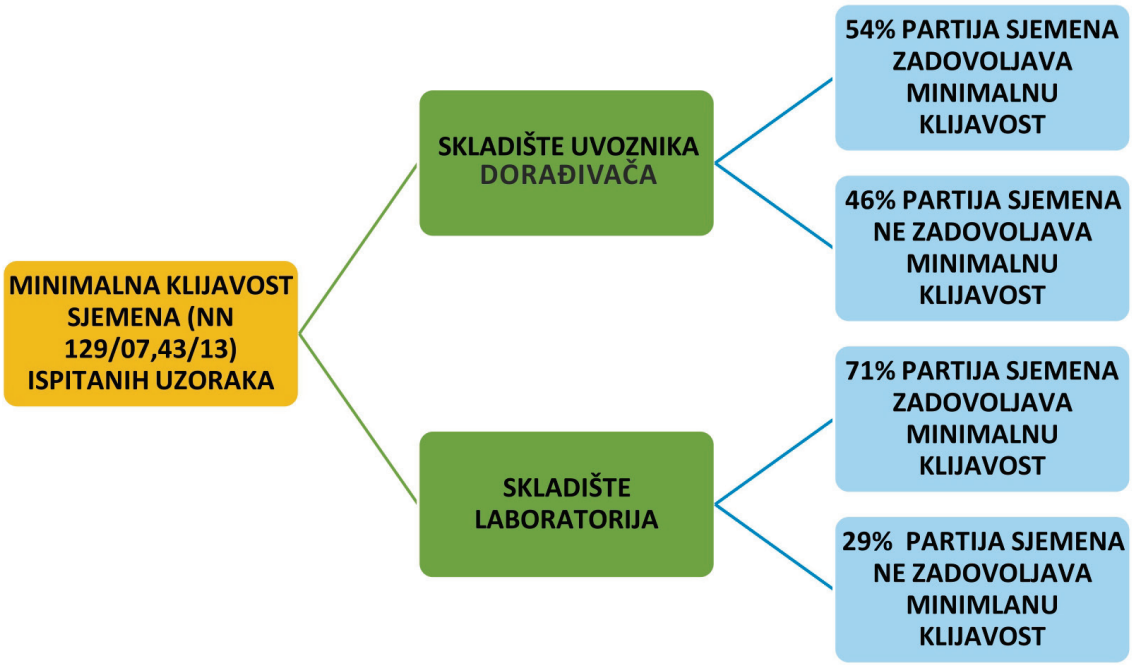

Sjeme povrtnih vrsta koje se prodaje na tržištu mora zadovoljavati minimalnu propisanu klijavost (NN 129/07, 43/13). Nakon provedenog istraživanja utvrđeno je da od ukupno 24 partije sjemena povrtnih vrsta uzorkovanih u skladištu dorađivača (uvoznika) njih 46\% ne zadovoljava minimalnu klijavost (celer listaš i korjenaš, peršin 
Dijana Horvat i sur.: Utjecaj uvjeta skladištenja

na klijavost sjemena povrtnih vrsta

listaš, špinat, paprika, poriluk, bob, kupus, brokula, salata i cikla), dok od istih partija sjemena uzorkovanih u skladištu laboratorija njih 29\% ne zadovoljava minimalnu propisanu klijavost (Slika 1.). Na pakiranjima istraživanih partija sjemena naveden je rok važenja tri godine, prema kojem bi sjeme trebalo biti na tržištu još jednu vegetacijsku sezonu jer je istraživanje provedeno 20 mjeseci nakon uvoza.

\section{ZAKLJUČAK}

Klijavost sjemena najvažniji je pokazatelj kvalitete sjemena, a prema provedenom istraživanju na duljinu klijavosti sjemena pojedinih biljnih vrsta utječu uvjeti skladištenja. Kako bi osigurali kvalitetno sjeme povrća na tržištu, uvoznici sjemena (dorađivači) bi trebali nakon svake sezone ispitati klijavost sjemena onih vrsta kod kojih je utvrđeno da sama vrsta utječe na duljinu klijavosti sjemena (celer, peršin, poriluk, špinat, paprika) ili certificirati te vrste na kraći rok od ostalih te ih ranije povući s tržišta. Sjeme svih povrtnih vrsta koje uvoze trebali bi skladištiti u kontroliranim uvjetima čime bi smanjili pad klijavosti kod vrsta osjetljivih na uvjete skladištenja (kupusnjače, salata, cikla) te povećali klijavost vrstama poput dinje, lubenice, krastavca, graha mahunara i patlidžana. Najveći doprinos kvaliteti sjemena povrća na tržištu postigli bi ugovaranjem proizvodnje sjemena sa domaćim proizvođačima jer osim navedenih faktora na kvalitetu sjemena utječu geografsko podrijetlo i lokacija uzgoja, a Hrvatska ima idealne uvjete za proizvodnju sjemena svih povrtnih vrsta.

\section{IMPACT OF STORAGE CONDITIONS ON GERMINATION OF VEGETABLE SEEDS}

\section{SUMMARY}

The seeds of vegetable species intended for hobby gardeners are mostly imported, of standard category and packed in small packages. Importers that carry out repacking of seeds ae obliged to have the seeds tested for germination capacity after repacking. They withdraw the unsold quantity of seed at the end of season and put it back on the market in the next two to three seasons without controlling germination capacity of seeds, leading to poor germination capacity or lack of germination capacity of the seeds sold on the market.

Research objective was to test germination capacity of 24 vegetable species on samples of seed batches stored in air-conditioned storage and on samples of the same batches that were on the market for two vegetation seasons and compare the germination capacity with the values obtained after the import of seeds. Research results indicate that germination capacity of the 
seeds of leaf celery (Apium graveolens var. secalinum L.), knobcelery (Apium graveolens L.), leafparsley (Petroselium crispumssp. crispum L.), leek (Allium porrum L.), broadbean (Vicia faba L.), pepper (Capsicum annuum L.) andspinach (Spinacia oleracea L.) is primarily influenced by plant species, where as storage conditions significantly influenced germination capacity of cabbage (Brassica oleracea L.), broccoli (Brassica oleracea L. var. italica), lettuce (Lactuca sativa L.) and red beet (Beta vulgaris L. var. conditiva). Out of 24 seed batches of vegetable species sampled in the storage of the processor (importer) $46 \%$ of them failed to meet there quirements for prescribed minimal germination capacity after 20 months, where as out of the same batches sampled in the storage room of the laboratory (controlled conditions) $29 \%$ of samples did not have sufficient germination capacity.

By means of ensuring optimal storage conditions and control of gerimantion capacityit is possible to positive lyaffect the quality of vegetable seeds on the market.

Key words: vegetable seeds, germination capacity, storage conditions

\section{LITERATURA}

1. Alhamdan, A.M., Alsadon, A.A., Khalil, S.O., Wahb-Allah, M.A., El Nagar, M. i Ibrahim, A.A. (2011.): Influence of storage conditions on seed quality and longevity of four vegetable crops. Am Eur J Agric Environ Sci, 11, pp.353-359.

2. Amjad, M. i M., A. Anjum (2002.): Effect of humidity and ageing period on the quality of onion seed. Int. J. Agri. \&Biol., 1560-8530/04-2-291-296.

3. Balešević-Tubić, S. (2001.): Uticaj procesa starenja na životnu sposobnost i biohemijske promene semena suncokreta. Doktorska disertacija, Poljoprivredni fakultet, Novi Sad.

4. Delouche, J. C. (1990.): Precepts of seed storage. Proc. Inter. Sat. Symp. Seed Sci. Technol Hisar :71-90.

5. Doijode, S. D. (2012.):Seed storage of horticultural crops. CRC Press.

6. $\quad$ Ellis, R.H.,Hong T. D., Roberts E. H. (1985.): Handbook of Seed Technology for Genebanks. Vol. I. Principle and Methodology. International Board for Plant Genetic Resources, Rome.

7. Elias, S., Garay, A., Young, B., Chastain, T. (2002.): Maintaining seed viability in storage: A briefre view of management principles with emphasis on grass seeds stored in Oregon. Technical Brochures. Seed Laboratory at Oregon State University

8. Hammer, Ø., Harper, D.A.T., Ryan, P.D. (2001.): PAST: Paleontologicalstatistics software package for educationand data analysis. Palaeontologia Electronica 4(1): 9pp. http://palaeoelectronica.org/2001_1/past/issue1_01.htm

9. James, E., Bass, L. N., Clark, D.C. (1967.):Varietal differences for longevity of vegetable seeds and their response to various storage conditions. Proc.Am.Soc. Hort. Sci., 91:521-528.

10. Kamau, K.S. i Maina, F.N.W., (2017.): Percentage Germination and Seedling Evaluation Parameters of Parsley (Petroselinum crispum) Seeds as Affectedby Different Priming Treatments and Durations. Journal of Agriculture and Ecology Research International, pp.1-5.

11. Lešić, R., Pavlek, P., Cvjetković, B. (1993.): Proizvodnja povrtnog sjemena. Agronomski fakultet Sveučilišta u Zagrebu, Arp. Zagreb.

12. McDonald, M. B. (1998.): Seedquality. Seed Science Research. 8: 265-275 


\section{Dijana Horvat i sur.: Utjecaj uvjeta skladištenja na klijavost sjemena povrtnih vrsta}

13. Ozcoban M, Demir I. (2002.): Longevity of pepper and water melon seeds in relation to seed moisture and storage temperature. Indian J. Agr. Sci. 2002;72:589-593.

14. Pravilnik o metodama uzorkovanja i ispitivanja kvalitete sjemena (NN 99/08 od 29.08.2008).

15. Pravilnik o stavljanju na tržište sjemena povrća (NN 129/07 od 17.12.2007)

16. Pravilnik o izmjenama i dopunama Pravilnika o stavljanju na tržište sjemena povrća (43/13 od 12.04.2013.)

17. Rao, R.G.S., P.M. Singh. i M. Rai, (2006.): Storability of onion seeds and effects of packaging and storage conditions on viability and vigour. Scientia Horticulturae, (110)1-6.

18. Rozman, V., Bukviš, G., Grljušiš S., Petroviš, S., Liška, A., Eđed, A., Rankoviš, V. (2009.): Utjecaj temperature skladištenja na svojstva sjemena i klijanaca engleskog ljulja. 44. hrvatski i 4. međunarodni simpozij agronoma, 16 - 20. veljače 2009. , zbornik sažetaka str.; 380 - 384, Sveučilište Josipa Juraja Strossmayera, Poljoprivredni fakultet u Osijeku

19. Schaffer, A. F., Vanderlip, R. L. (1999.): The effect of conditioning on soybean seed quality. Journal of Production Agriculture, 12: 455-459

20. Shad AA, Shah HU, Bakht J, Choudhary MI \&Ullah J (2011.): Nutraceutical potential and bioassay of Apium graveolens L. grownin Khyber Pakhtunkhwa-Pakistan. Journal of Medicinal Plants Research, 5:5160-5166.

21. Skromak, A. (2016.): Inhibitori klijanja u sjemenu mrkve, peršina i kopra i njihovo uklanjanje ispiranjem. Diplomski rad, Agronomski fakutet Sveučilišta u Zagrebu

22. Vieira, R., D., TeKrony, D., M., Egli, D., B., Rucker, M. (2001.): Electrical conductivity of soybean seeds after storage in several environments. Seed Science and Technology, 29: 599-608

Adrese autora - Author's address:

dr.sc. Dijana Horvat, e-mail: dhorvat@vguk.hr

Iva Rojnica,

Ivana Koprivnjak

Visoko gospodarsko učilište u Križevcima

Milislava Demerca 1

48260 Križevci

Marina Palfi,

Helena Tomić Obrtalj

Podravka d.d., Istraživanje i razvoj

Ante Starčevića 32,

48000 Koprivnica

Hrvatska
Primljeno - Received:

30.06.2020. 
